\title{
Pleomorphic xanthoastrocytoma: a brief review
}

\author{
Nawal Shaikh1, Nupur Brahmbhatt ${ }^{2}$, Tim J Kruser ${ }^{3,4}$, Kwok L Kam ${ }^{5}$, Christina L Appin ${ }^{3,5}$ \\ Nitin R Wadhwani ${ }^{6}$, James Chandler ${ }^{3,7}$, Priya Kumthekar ${ }^{2,3}$ \& Rimas V Lukas*,2,3 \\ ${ }^{1}$ Department of Neurology, University of Mississippi Medical Center, 2500 N. State Street, Jackson, MS 39216, USA \\ ${ }^{2}$ Department of Neurology, Northwestern University, Chicago, IL 60611, USA \\ ${ }^{3}$ Lou \& Jean Malnati Brain Tumor Institute at the Lurie Comprehensive Cancer Center, Northwestern University in Chicago, IL \\ 60611, USA \\ ${ }^{4}$ Department of Radiation Oncology, Northwestern University, Chicago, IL 60611, USA \\ ${ }^{5}$ Department of Pathology, Northwestern University, Chicago, IL 60611, USA \\ ${ }^{6}$ Department of Pathology \& Laboratory Medicine, Ann \& Robert H Lurie Children's Hospital of Chicago, IL 60611, USA \\ ${ }^{7}$ Department of Neurological Surgery, Northwestern University, Chicago, IL 60611, USA \\ *Author for correspondence: rimas.lukas@nm.org
}

Pleomorphic xanthoastrocytoma (PXA) is a rare primary CNS tumor. Recent advances in the molecular characterization are helping to define subtypes of tumor. The discovery of BRAF mutations within a substantial percentage of PXA fosters a clearer understanding of the pathophysiology of these tumors with clear prognostic and therapeutic implications. These findings are expected to provide insight into the spectrum of clinical behavior observed in PXA, ranging from cure with surgery to diffuse dissemination throughout the neuraxis. This review details the clinical presentation including radiographic appearance of PXA. Pathology, including molecular pathology is discussed. Therapeutic management including surgical resection, radiotherapy and systemic therapies are reviewed.

First draft submitted: 6 June 2019; Accepted for publication: 9 August 2019; Published online: 19 September 2019

Keywords: BRAF $\bullet$ pathology $\bullet$ pleomorphic xanthoastrocytoma $\bullet$ PXA • radiation $\bullet$ surgery

Pleomorphic xanthoastrocytoma (PXA) is an astrocytic tumor thought to originate from subpial astrocytes or their precursors. It is rare and accounts for $<1 \%$ of all astrocytomas. First described in 1973 [1] the term PXA was coined by Kepes in 1979 [2]. In 1993, it was formally incorporated in the WHO classification system of tumors of the central nervous system (CNS) as a WHO grade 2 tumor. Subsequent descriptions include anaplastic grade 3 variants. It is likely that the term PXA while describing a single histologic entity may represent more than one tumor type as defined molecularly. A similar evolution of thought has been seen with respect to other glial tumors. The varying descriptions of the natural history of this disease appear to support this hypothesis.

The epidemiologic perspective on PXA is limited. While listed as its own distinct entity in Surveillance, Epidemiology, and End Results (SEER), in the Central Brain Tumor Registry of the United States (CBTRUS), PXA is classified under the umbrella term 'unique astrocytoma variants' [3]. In SEER only 214 cases had been reported between 1981 and 2007 in the USA [4]. This is approximately one-tenth the incidence of pilocytic astrocytomas, another rare CNS tumor.

\section{Clinical presentation}

PXA is most commonly diagnosed in the second decade of life [5-7]. Mean age at diagnosis is $29 \pm 16$ years [5-7]. But cases as young as 2 and as old 68 have been reported [5,6]. The majority of large case series have reported no gender predilection. Presenting symptoms can be broadly classified as localizable or nonlocalizable. Localizable symptoms correlate directly with the neuroanatomy involved with tumor. These include seizure, the most frequent initial presenting symptom. Nonlocalizable symptoms are related to elevation of intracranial pressure and include 


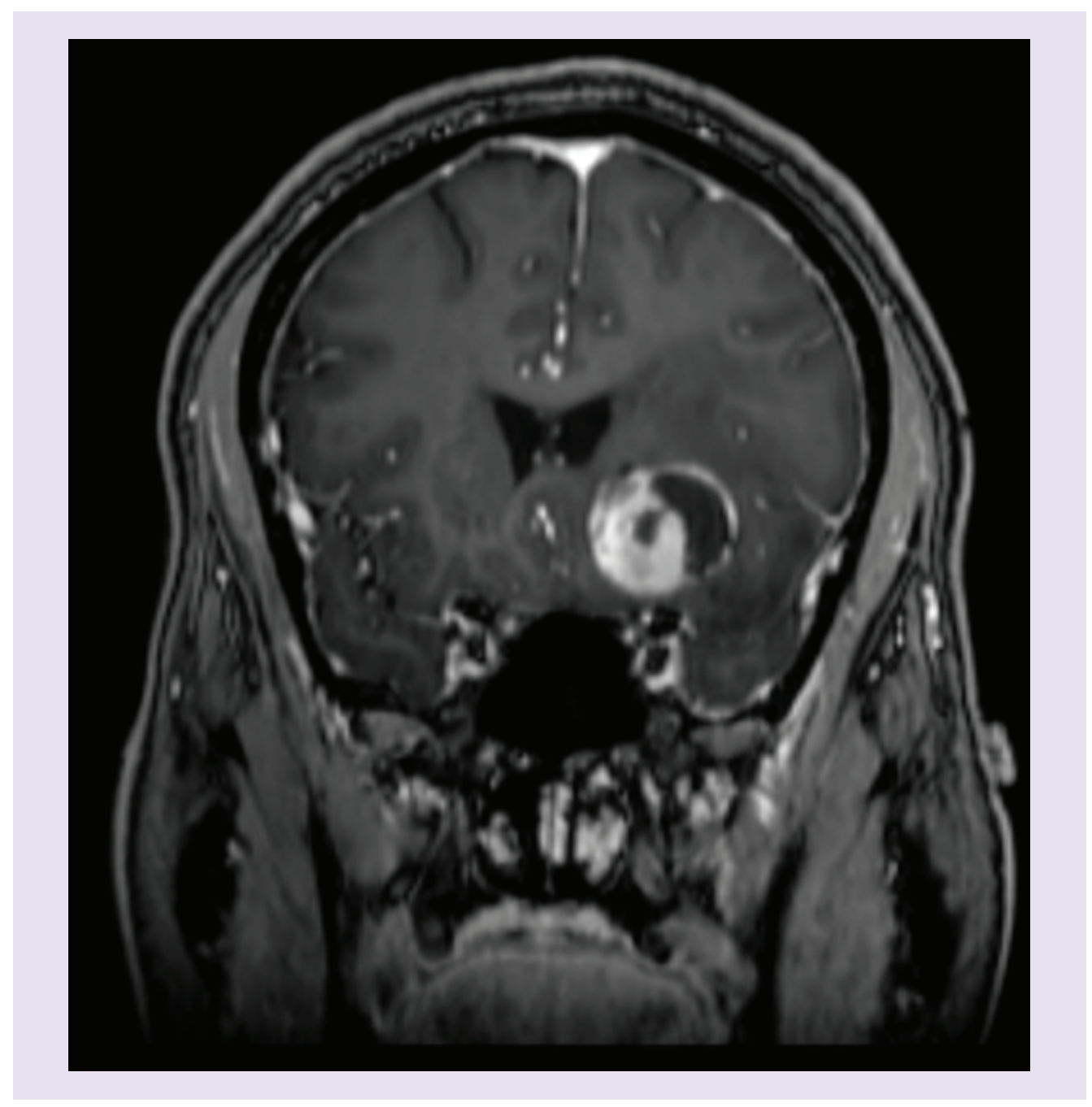

Figure 2. Coronal T1 postcontrast magnetic resonance imaging revealing a left frontal enhancing lesion with cystic components. A distinct delineation between tumor and surrounding brain parenchyma is noted.

headaches, nausea, vomiting, diplopia and somnolence. The mean duration of symptomatology prior to diagnosis is a few months. Rarely, these tumors are incidentally found when imaging is performed for other indications.

While described throughout the CNS, the temporal lobe is the most common location of PXAs, even when they occur in a multifocal fashion [5,7-11]. These tumors have the potential to spread via the cerebrospinal fluid (CSF). This is most commonly seen in the progressive/recurrent disease setting. Only a limited number of patients present with CSF disseminated disease at their initial diagnosis. Tumor grade and the potential for dissemination are not consistent across studies [12-15].

\section{Imaging}

Despite their generally favorable natural history, PXA appears ominous on imaging with some features reminiscent of high-grade gliomas. They occur most commonly as well circumscribed superficial masses with leptomeningeal contact. These tumors often consist of solid and cystic components. On contrast enhanced computed tomography imaging, the cystic component is hypodense. The solid component typically appears hypo to isodense, but can occasionally be hyperdense, with areas of calcification seen in the solid component. The solid component as well as the wall of the cyst often enhances. MRI reveals T1 isointense, T2 hyperintense and T1 post gadolinium heterogeneously contrast enhancing solid component with peripheral rim enhancement of the cyst (Figure 2). The cystic fluid is either isointense or hyperintense as compared with CSF depending on the imaging sequence. A minimal amount of vasogenic edema around the lesion can be seen at times. Leptomeningeal enhancement is seen 


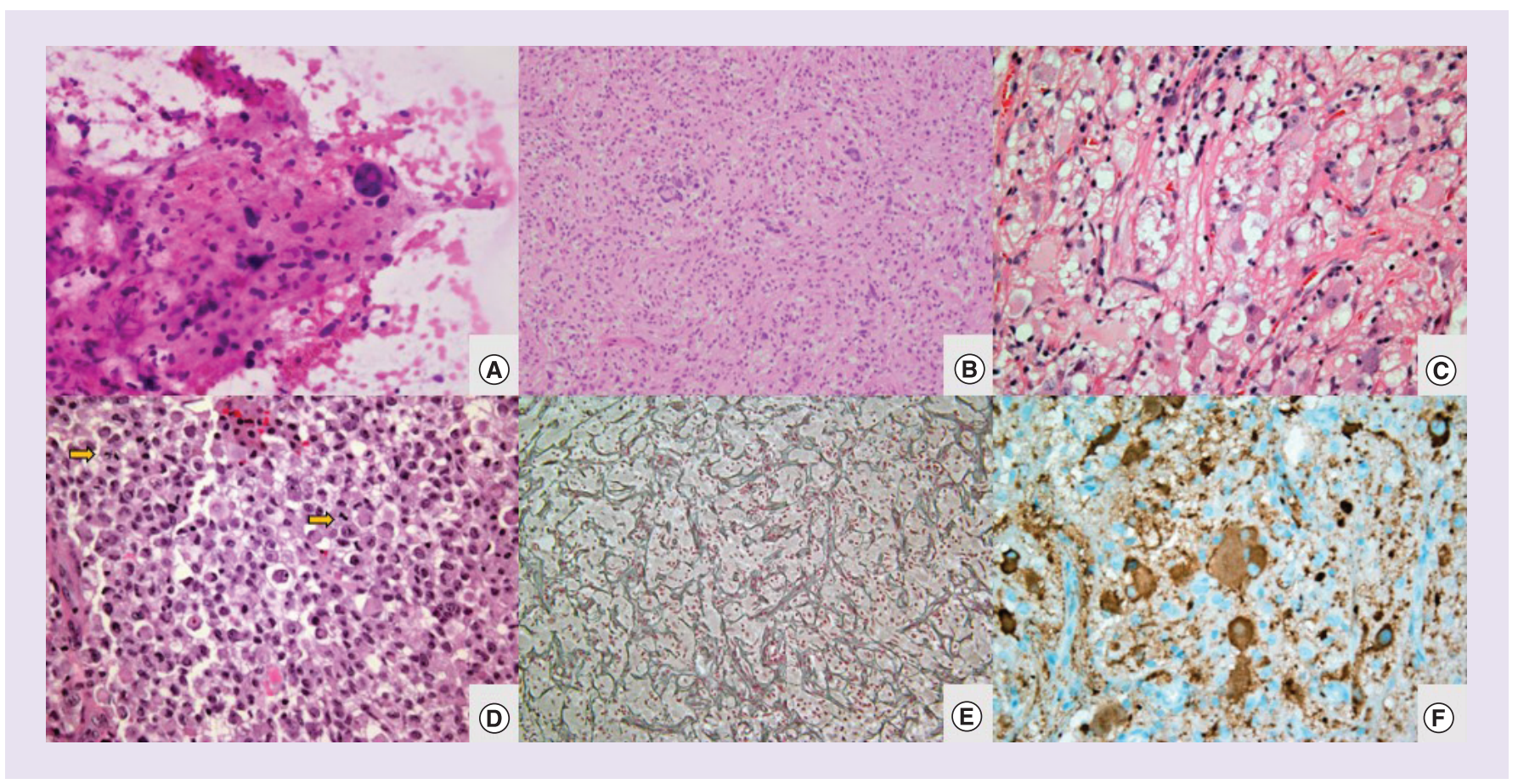

Figure 1. Histopathology of pleomorphic xanthoastrocytoma. (A) The smear preparation shows highly pleomorphic tumor cells with occasional bizarre-looking nuclei $(\mathrm{H} \& \mathrm{E}, \times 400)$. (B) There is an admixture of spindelled neoplastic and neoplastic cells with bizarre nuclei or multinucleation $(H \& E, \times 200)$. (C) The neoplastic cells show multivacuolated cytoplasm $(H \& E, \times 400)$. (D) An anaplastic pleomorphic xanthogranuloma showing paradoxically monomorphic tumor cells with increased cellularity. Scattered mitotic figures (arrows) are noted $(\mathrm{H} \& \mathrm{E}, \times 200)$. (E) Reticulin stain shows a rich reticulin network surrounding nests of tumor cells. Occasional pericellular reticulin deposition is also noted (reticulin stain, $\times 200$ ). (F) Synaptophysin immunohistochemical stain highlights pleomorphic tumor cells (synaptophysin, $\times 400)$.

H\&E: Hematoxylin and eosin stain.

\section{Table 1. Immunohistochemical characteristics of pleomorphic xanthoastrocytoma.}

\begin{tabular}{llllllll} 
IHC stain & GFAP & S100 & Vimentin & Reticulin & PAS & Synaptophysin \\
PXA & +++ & +++ & +++ & +++ & +++ & - & + \\
\hline
\end{tabular}

EMA: Epithelial membrane antigen; GFAP: Glial fibrillary acidic protein; IHC: Immunohistochemistry; PAS: Periodic acid-Schiff; PXA: Pleomorphic xanthoastrocytoma.

in a subset of patients [9-11,16]. PXA is hypovascular on angiography [17]. On fluorodeoxy glucose (FDG) positron emission tomography (PET), it has shown high glucose metabolism and hypoperfusion on SPECT perfusion scans [18].

\section{Pathology}

As with other primary CNS tumors, molecular characterizations have a growing role in the classification of PXA. This has not yet been formalized in the WHO classification system. However, in contemporary practice, PXA can now be divided into $B R A F$ mutated and $B R A F$ wild-type. This has both diagnostic and potential therapeutic implications.

\section{Gross \& histologic description}

PXA (WHO grade II) is an astrocytic tumor that grossly appears as a superficial solid and cystic mass with involvement of the leptomeninges common. This tumor is most frequently located in the temporal lobe. Its histopathology was first described after microscopic review of 12 almost identical appearing cases [1]. It is a moderately cellular, predominantly pleomorphic tumor with foci of lymphoplasmacytic infiltration without any necrosis and rare mitoses (Figure $1 \&$ Table 1) $[1,2,5,7,11,13,14,15,20]$. The tumor cells are either spindle shaped with elongated nuclei or large round cells with a single or multilobulated nucleus or multiple nuclei (bizarre multinucleate 
giant cells) that invade the brain parenchyma directly or at the perivascular spaces. There is also evidence of external basal lamina on electron microscopy, which consists of reticulin fibers produced and present around the tumor cells. This finding points toward the potential origin of PXA from subpial fibrous astrocytes [19-21]. The cytoplasm of the tumor cells is eosinophilic and contains varying amounts of hyaline protein and lipid droplets. The cytoplasm is positive for glial fibrillary acidic protein (GFAP) on immunohistochemistry, a marker also positive in other glial neoplasms. GFAP positivity varies depending on the lipid content of the cytoplasm [2]. Unique histopathology with abundant clear cell component and focal papillary appearance has also been reported [22]. The varying morphologies within tumors highlight the pleomorphic nature of the tumor.

\section{Anaplasia}

In 1983 the first case of recurrent PXA with malignant (WHO grade III) transformation was described [19]. Both de novo presentation as a grade III tumor and progression of grade II-III have been described [23]. PXA in earlier WHO classification systems was categorized strictly as a grade II tumor, but the 2016 update of the WHO classification now also includes grade III anaplastic PXA (aPXA). aPXA is primarily defined by the presence of necrosis accompanying high mitotic activity usually $>5$ mitoses $/ 10$ high powered fields (HPF), and increased cellularity. Pseudorosette formation resembling ependymomas and focal endothelial proliferation has been reported [12,23,24]. MIB-1 labeling index cutoff is generally considered to be $>4 \%$ [25-30]. aPXA has the potential of CSF spread, higher chance of recurrence and hence shorter progression-free and overall survivals (PFS and OS, respectively) [5,18,19,31-33].

\section{Molecular features}

The most frequently found mutated gene in PXAs is BRAF, which encodes an intracellular component of the MAPK pathway. BRAF is one of the three RAF (rapidly accelerated fibrosarcoma) kinases that is most commonly mutated and has the highest oncogenic potential [34-37]. BRAF mutations can be found in 70\% of typical PXA, but appears less common in aPXAs, with a variable range reported (17-65\%) [34,38-40]. Mutations that have been described in PXAs include activating BRAF p.V600E mutations, in frame deletions within BRAF exon and less often BRAF fusions [41]. BRAF mutation may divide these tumors into two clinically relevant subgroups, both with regards to natural history and response to therapy. $B R A F$-mutated PXA exhibits superior survival when compared with the $B R A F_{\mathrm{wt}}$ [38]. The $B R A F$-mutated PXA also exhibits responses to BRAF targeting therapies [42] although no comparative prospective trials have been conducted in this patient population.

There have been reports of EGFR amplification found in glioblastoma (GBM) arising from malignant transformation of PXA. However, this is not common and may represent initial misdiagnosis of glioblastoma. Aberrations in 553 and p16, loss of heterozygosity of chromosome 10 are thought to be contributing to PXA formation and progression [21,41,43-45]. Mutations in p53 can occur in up to $25 \%$ of patients with PXA [43].

With the advent of immuno-oncology and its active investigation within the field of neuro-oncology, an interest exists in potential predictive biomarkers for response to immunotherapies in glial tumors. A number of candidate biomarkers have been suggested in glial tumors, including expression of programmed death 1 and its ligand [46], tumor mutational burden [47] and microsatellite instability [48]. However, programmed death $1 /$ programmed death ligand 1 expression, tumor mutational burden and microsatellite instability in PXA have not been reported thus far, to our knowledge. Recent studies demonstrating MAPK pathway (including BRAF) alterations in glioblastoma can confer benefit with immunotherapies [49] may have direct relevance to PXA. This will require further study.

\section{Prognosis}

PXA is a rare glial tumor with relatively favorable prognosis. There are several retrospective studies evaluating potential intrinsic and modifiable prognostic biomarkers. Tumor intrinsic factors such as elevated mitotic index ( $>5$ mitosis/10 HPF) and presence of necrosis, features consistent with aPXA, are associated with decreased OS and PFS on multivariate analyses [2,50]. In contrast, the presence of BRAF V600 mutations is associated with longer OS rates [38]. While clear radiographic responses have been seen in these patients when BRAF inhibition is utilized, the mutational status has not yet been validated as a predictive factor for response to BRAF inhibitors.

OS of PXA is favorable with 3- and 5-year survival rates of $>80$ and $>75 \%$, respectively [5,51]. PFS rates at 3 and 5 years are $>60 \%$ [5,51]. This diminishes with increasing grade/anaplasia. aPXA has 5-year OS rate of $57 \%$ and PFS of 49\% [32,52]. It must be kept in mind that a subset of patients with PXA is deemed to be cured of disease, even with surgical resection alone. This distinguishes PXA from other infiltrating gliomas. 


\section{Therapeutic management}

Due to the rarity of the tumor there are no formal guidelines published on management. Optimal management is guided by case reports and case series. We highlight key concepts below.

\section{Surgery}

Conflicting reports exist on the importance of extent of resection (EOR) [50,51,53]. However, multiple groups have reported it as a reliable prognostic factor for OS and PFS [5,54], with a gross total resection correlating with 10-year OS of $82 \%$ [55]. As a routine practice, gross total resection (GTR), if feasible and safe, should be the goal of the surgeon.

\section{Radiotherapy}

Scant data exist to guide the utilization of radiotherapy (RT) in PXA. Some reports have noted an association with use of postoperative RT and improved PFS [2,26,51,53], but no definitive improvement in OS has been demonstrated. A recent meta-analysis of 167 patients with grade II PXA did not demonstrate an association between adjuvant therapy with improved oncologic outcomes; the majority of patients (76\%) had RT utilized as a salvage treatment upon recurrence [56]. Given the paucity of data, using RT doses in the range of 45-54 Gy for either adjuvant or salvage treatment appears reasonable, with or without concurrent temozolomide. Earlier incorporation of radiation for subtotal resection and/or aPXA may be considered given the poorer outcomes associated with these factors. Craniospinal RT may be warranted for leptomeningeal dissemination on recurrence or at initial diagnosis $[20,27,57]$.

\section{Systemic therapy}

Limited data exist on systemic chemotherapeutic agents from PXA tumors. Traditional chemotherapy has been generally considered minimally effective or ineffective for the treatment of PXAs (Table 2) [2,5,51]. However, in progressive disease when surgery or RT is not always a viable option, systemic treatments are often considered and employed.

Molecular markers are increasingly utilized to aid diagnosis and to subclassify glial tumors. In PXA where there is a high incidence of targetable mutations this is of particular importance. There have been a number of reports utilizing BRAF inhibitor monotherapy or BRAF+MEK inhibitors. Favorable responses have ranged from stable disease to complete responses [58-64]. In the largest published nonrandomized trial over $40 \%$ of patients with PXA treated with BRAF-inhibiting monotherapy exhibited radiographic response. More than half were noted to have a confirmed clinical benefit [63]. The addition of bevacizumab to this regimen at time of progression may prolong survival [64]. The utilization of BRAF inhibitor in conjunction with tumor-treating fields (TTFields) has also been reported [65].

\section{Conclusion}

PXA is a rare tumor ranging from WHO grade II to III, which has the potential to recur and to disseminate throughout the CNS. A broad range of outcomes can be seen ranging from cure of disease with single modality treatment (i.e., surgery) to rapid progression with CSF dissemination. This underlines a point seen in other infiltrating gliomas; while the histologic phenotype may be the same, molecular phenotypes may define distinct subtypes or types of disease. Our understanding of the molecular characteristics of the disease is of particular importance as they influence not only prognosis but also our therapeutic management. Notable radiographic responses have been seen with BRAF inhibitor-centered regimens. While the rarity of the disease will make definitive therapeutic studies difficult, we would anticipate that our clinical management for patients with this disease will evolve rapidly in the near future.

\section{Future perspective}

It is anticipated that the molecular neuropathology will play an increasingly important role in defined CNS tumors, including PXA [66]. The presence of BRAF driver mutations in a subset of PXA may be a more unifying feature tying them both pathophysiologically and in turn therapeutically to other relatively low-grade glial tumors. The value of these molecular features may supersede the identical histologic features of $B R A F$-mutated and $B R A F$ wild-type PXA in the way clinicians and investigators conceptualize these tumors. It is likely that while level 1 evidence may be lacking, BRAF pathway-directed therapies will become standard treatments for $B R A F$-mutated PXA. The optimal future therapies for $B R A F$ wild-type PXA are less clear. While complete surgical resection and RT will continue to 
Table 2. Systemic therapies evaluated in pleomorphic xanthoastrocytoma.

\begin{tabular}{|c|c|c|c|c|c|c|c|c|}
\hline Year & Study & $\mathbf{N}$ & RT & Systemic regimen & Setting & PFS & os & Ref. \\
\hline $\begin{array}{l}1979 \text { and } \\
1989\end{array}$ & $\begin{array}{l}\text { Kepes and } \\
\text { Whittle et al. }\end{array}$ & 4 & $\begin{array}{l}\text { Adjuvant } 45 \text { Gy } \\
\text { WBRT; } 55 \text { Gy WBRT }\end{array}$ & NA & $\begin{array}{l}\text { On initial presentation of } \\
\text { typical PXA but STR; on } \\
\text { first recurrence of PXA }\end{array}$ & $\begin{array}{l}11-14 \text { years; } 8 \\
\text { months }\end{array}$ & NA & {$[2,39]$} \\
\hline 1983 & $\begin{array}{l}\text { Weldon Linn } \\
\text { et al. }\end{array}$ & 2 & $65 \mathrm{~Gy}$ in 7 weeks & NA & $\begin{array}{l}\text { On initial presentation of } \\
\text { typical PXA }\end{array}$ & $\begin{array}{l}1.5 \text { years; } 18 \\
\text { months }\end{array}$ & $\begin{array}{l}\text { Close to } 2 \\
\text { years; } 21 \\
\text { months }\end{array}$ & [3] \\
\hline 1985 & Bukeo et al. & 1 & $\begin{array}{l}\text { Adjuvant focal RT } \\
59.6 \mathrm{~Gy}\end{array}$ & NA & $\begin{array}{l}\text { On initial presentation of } \\
\text { aPXA and STR }\end{array}$ & 5 years & NA & [36] \\
\hline 1987 & Iwaki et al. & 3 & $40 ; 50 ; 60$ Gy focal RT & NA & $\begin{array}{l}\text { On initial presentation as } \\
\text { it was aPXA. One on } \\
\text { recurrence of aPXA }\end{array}$ & $\begin{array}{l}6 \text { years; } 17 \text { years; } \\
4 \text { months }\end{array}$ & NA & [32] \\
\hline 1988 & Gaskill et al. & 1 & Spinal RT & CCNU, vincristine, prednisone & $\begin{array}{l}\text { On recurrence and } \\
\text { re-resection }\end{array}$ & 8 months & 11 months & [29] \\
\hline 1988 & Stuart et al. & 1 & Adjuvant focal RT & NA & $\begin{array}{l}\text { On initial presentation of } \\
\text { typical PXA }\end{array}$ & 3 years & NA & [38] \\
\hline 1989 & Kepes et al. & 5 & $\begin{array}{l}\text { Adjuvant } 30-40 \text { Gy or } \\
46.3 \text { Cobalt focal RT; } \\
36.8 \text { Cobalt WBRT to } \\
\text { resection cavity on } \\
\text { first recurrence }\end{array}$ & NA & $\begin{array}{l}\text { On initial presentation of } \\
\text { typical PXA and GTR. For } \\
\text { last case, adjuvant RT was } \\
\text { on recurrence of PXA with } \\
\text { GBM component }\end{array}$ & $\begin{array}{l}7-8 \text { months; } 6 \\
\text { years; } 4.5 \text { years; } \\
17 \text { years; } 3 \text { years }\end{array}$ & $\begin{array}{l}\text { Unknown; } 6 \\
\text { years and few } \\
\text { months; } \\
\text { unknown; } \\
\text { unknown; >6 } \\
\text { years }\end{array}$ & [37] \\
\hline 1991 & Allegranza et al. & 1 & $\begin{array}{l}\text { Adjuvant } \mathrm{RT} \text { to } \\
\text { resection cavity }\end{array}$ & NA & On first recurrence aPXA & 2 years & NA & [41] \\
\hline 1992 & Zorsi et al. & 2 & $\begin{array}{l}\text { Adjuvant } 30 \mathrm{~Gy} \text {; } \\
60 \text { Gy focal RT }\end{array}$ & NA & $\begin{array}{l}\text { On initial presentation } \\
\text { and on recurrence of PXA }\end{array}$ & 16 years; unsure & NA & [40] \\
\hline 1993 & Macaulay et al. & 1 & $\begin{array}{l}\text { Concomitant RT } \\
54 \text { Gy in } 30 \text { fractions } \\
\text { over } 6 \text { weeks }\end{array}$ & $\begin{array}{l}\text { Eight cycles of ifosfamide, } \\
\text { carboplatin and etoposide after } \\
\text { re-resection }\end{array}$ & $\begin{array}{l}\text { On recurrence of } \\
\text { anaplastic pleomorphic } \\
\text { xanthoastrocytoma } \\
\text { (APXA) now with GBM } \\
\text { component }\end{array}$ & 2 years & NA & [22] \\
\hline 1997 & Perry et al. & 1 & $\mathrm{RT}$ to resection cavity & Adjuvant chemotherapy & $\begin{array}{l}\text { On initial presentation as } \\
\text { there was a ganglioglioma } \\
\text { component }\end{array}$ & & 4 years & [30] \\
\hline 1997 & Perry et al. & 1 & $\mathrm{RT}$ to resection cavity & Adjuvant chemotherapy & $\begin{array}{l}\text { On initial presentation as } \\
\text { it was an STR and had } \\
\text { ganglioglioma component }\end{array}$ & 1 year & NA & [30] \\
\hline 1998 & Leonard et al. & 1 & $\begin{array}{l}50 \mathrm{~Gy} \text { in } 30 \text { fractions } \\
\text { to resection cavity }\end{array}$ & Temozolomide & On first recurrence & 4 months & 11 months & [25] \\
\hline 1999 & $\begin{array}{l}\text { Chakrabarty } \\
\text { et al. }\end{array}$ & 2 & Focal RT & NA & $\begin{array}{l}\text { On initial presentation as } \\
\text { it was aPXA }\end{array}$ & & NA & [31] \\
\hline 2001 & Primavera et al. & 1 & $\begin{array}{l}60 \text { Gy in } 30 \text { fractions } \\
\text { focal RT after } \\
\text { re-resection }\end{array}$ & $\begin{array}{l}\text { Adjuvant five courses of } \\
\text { chemotherapy with } \\
\text { procarbazine, CCNU and } \\
\text { vincristine }\end{array}$ & On recurrence of $A P X A$ & 1.5 years & NA & [33] \\
\hline 2001 & Perry et al. & 1 & $\begin{array}{l}54 \text { Gy focal RT in } 30 \\
\text { fractions }\end{array}$ & NA & $\begin{array}{l}\text { First recurrence of mixed } \\
\text { PXA and } \\
\text { oligodendroglioma }\end{array}$ & 17 months & NA & [21] \\
\hline 2001 & Cartmill et al. & 1 & & $\begin{array}{l}\text { Neoadjuvant chemotherapy with } \\
\text { the goal of antiangiogenesis } \\
\text { comprising of vincristine and } \\
\text { cisplatin two cycles over } 6 \text { weeks } \\
\text { followed by resection }\end{array}$ & $\begin{array}{l}\text { On initial presentation of } \\
\text { PXA }\end{array}$ & 2 months & NA & [42] \\
\hline 2004 & Lubansu et al. & 1 & & $\begin{array}{l}\text { Alternating cycles of } \\
\text { carboplatin/VP-16, } \\
\text { cyclophosphamide and } \\
\text { vincristine. POD refractory to } \\
\text { further chemotherapy including } \\
\text { temozolomide, thiotepa and } \\
\text { daily VP-16 }\end{array}$ & On initial presentation & 7 months & NA & [18] \\
\hline 2004 & Tan et al. & 1 & $\begin{array}{l}60 \text { Gy focal RT over } 6 \\
\text { weeks after second } \\
\text { resection }\end{array}$ & NA & $\begin{array}{l}\text { On recurrence of PXA into } \\
\text { aPXA }\end{array}$ & 6 months & NA & [23] \\
\hline
\end{tabular}




\begin{tabular}{|c|c|c|c|c|c|c|c|c|}
\hline Year & Study & $\mathbf{N}$ & RT & Systemic regimen & Setting & PFS & os & Ref. \\
\hline 2005 & Nakajima et al. & 1 & $\begin{array}{l}30 \text { Gy CSI with } 30 \text { Gy } \\
\text { boost to resection } \\
\text { cavity }\end{array}$ & Adjuvant ACNU & $\begin{array}{l}\text { On second recurrence of } \\
\text { GBM transformation of } \\
\text { typical PXA }\end{array}$ & 3 years & NA & [34] \\
\hline 2005 & Saikali et al. & 1 & $\begin{array}{l}60 \text { Gy focal RT on first } \\
\text { recurrence }\end{array}$ & $\begin{array}{l}4 \text { cycles TMZ on second } \\
\text { recurrence APXA - no response } \\
\text { treated with re-resection. PCV for } \\
\text { third recurrence }\end{array}$ & On first recurrence of PXA & $\begin{array}{l}1 \text { year; contd. } \\
\text { Progression on } \\
\text { second } \\
\text { recurrence with } \\
\text { TMZ; } 4 \text { months } \\
\text { with } \\
\text { re-resection }\end{array}$ & NA & [35] \\
\hline 2008 & Koga et al. & 1 & $\begin{array}{l}\text { SRS to first } \\
\text { recurrence then to } \\
\text { multiple lesions }\end{array}$ & NA & $\begin{array}{l}\text { On first recurrence of PXA; } \\
\text { on second recurrence }\end{array}$ & $\begin{array}{l}6 \text { months; } 44 \\
\text { months }\end{array}$ & NA & [43] \\
\hline 2018 & Byun et al. & 4 & Adjuvant focal RT & NA & $\begin{array}{l}\text { On initial presentation of } \\
\text { aPXA }\end{array}$ & 6 months & NA & [20] \\
\hline
\end{tabular}

be the components of the standard of care for both PXA subtypes, novel therapeutics may be of interest for the less treatment responsive $B R A F$ wild-type tumors.

There are ongoing studies, in both adult and pediatric populations, focused on glial tumors, which have enrollment open to patients with PXA. These include trials of targeted therapeutics such as BRAF inhibitor (dabrafenib) in combination with MEK inhibitor (rametinib) (NCT02684058), a cyclin D1/CDK4/CDK6 inhibitor (ribociclib) in combination with an MEK inhibitor (rametinib) (NCT03434262), the antiparasitic mebendazole in conjunction with traditional cytotoxic chemotherapies (NCT01837862) and intratumoral injection of an oncolytic recombinant polio virus/rhinovirus (PVSRIPO) (NCT03043391). Results of these studies may help confirm suspected therapeutic targets or provide new avenues for further investigation. The speed of progress will likely be limited by the relative rarity of these tumors and the associated difficulty of clinical investigations in this patient population.

\section{Executive summary}

- Pleomorphic xanthoastrocytoma (PXA) is a rare astrocytic tumor with the potential for cerebrospinal fluid dissemination.

- Over two-thirds of PXA harbor mutations in BRAF.

- Presence of BRAF mutation confers a more favorable natural history and the potential for response to BRAF inhibition.

- The 5-year survival with PXA is $>75 \%$; however, tumors with anaplastic features exhibit less favorable outcomes.

- Complete surgical resection is a cornerstone of the management of these tumors.

- Radiotherapy may play a role for residual or recurrent disease.

- Traditional systemic therapies have proven of limited benefit in treating PXA.

- BRAF inhibition, alone or in combination with other treatments including MEK inhibition, has been associated with marked radiographic responses in BRAF-mutated PXA.

- Novel treatment strategies are under clinical investigation for PXA typically within the context of basket trials. However, they are hampered by the relative rarity of this tumor.

\section{Acknowledgments}

The authors thank W Barry for assistance with preparation and submission of the manuscript.

\section{Financial \& competing interests disclosure}

PK and RVL are supported by P50CA221747 SPORE for Translational Approaches to Brain Tumors. The authors have no other relevant affiliations or financial involvement with any organization or entity with a financial interest in or financial conflict with the subject matter or materials discussed in the manuscript apart from those disclosed.

No writing assistance was utilized in the production of this manuscript. 
Open access

This work is licensed under the Attribution-NonCommercial-NoDerivatives 4.0 Unported License. To view a copy of this license, visit http://creativecommons.org/licenses/by-nc-nd/4.0/

\section{References}

Papers of special note have been highlighted as: $\bullet$ of interest; $\bullet \bullet$ of considerable interest

1. Kepes JJ, Kepes M, Slowik F. Fibrous xanthomas and xanthosarcomas of the meninges and the brain. Acta Neuropathol. 23(3), 187-199 (1973).

-• Initial description of pleomorphic xanthoastrocytoms.

2. Kepes J, Rubinstein L, Ansbacher L, Schreiber D. Histopathological features of recurrent pleomorphic xanthoastrocytomas: further corroboration of the glial nature of this neoplasm. Acta Neuropathol. 78(6), 585-593 (1989).

3. Ostrom QT, Gittleman H, Liao P et al. CBTRUS statistical report: primary brain and other central nervous system tumors diagnosed in the United States in 2010-2014. Neuro Oncol. 19(Suppl. 5), v1-v88 (2017).

4. National Cancer Institute. SEER cancer statistics review (CSR) 1975-2015. Noone AM, Howlader N, Krapcho M et al.. (Eds). MD, USA. https://seer.cancer.gov/csr/1975_2015/

5. Giannini C, Scheithauer BW, Burger PC et al. Pleomorphic xanthoastrocytoma: what do we really know about it? Cancer 85(9), 2033-2045 (1999).

6. Davies KG, Maxwell RE, Seljeskog E, Sung JH. Pleomorphic xanthoastrocytoma - report of four cases, with MRI scan appearances and literature review. Br. J. Neurosurg. 8(6), 681-689 (1994).

7. Lipper MH, Eberhard DA, Phillips CD, Vezina L-G, Cail WS. Pleomorphic xanthoastrocytoma a distinctive astroglial tumor: neuroradiologic and pathologic features. Am. J. Neuroradiol. 14(6), 1397-1404 (1993).

8. Preusser M, Bienkowski M, Birner P. BRAF inhibitors in BRAF-V600 mutated primary neuroepithelial brain tumors. Expert Opin. Invest. Drugs 25(1), 7-14 (2016).

9. Crespo-Rodríguez AM, Smirniotopoulos JG, Rushing EJ. MR and CT imaging of 24 pleomorphic xanthoastrocytomas (PXA) and a review of the literature. Neuroradiology 49(4), 307-315 (2007).

10. Yu S, He L, Zhuang X, Luo B. Pleomorphic xanthoastrocytoma: MR imaging findings in 19 patients. Acta Radiol. 52(2), 223-228 (2011).

11. Gil-Gouveia R, Cristino N, Farias J, Trindade A, Ruivo N, Pimentel J. Pleomorphic xanthoastrocytoma of the cerebellum: illustrated review. Acta. Neurochirurgica. 146(11), 1241-1244 (2004).

12. Lubansu A, Rorive S, David P et al. Cerebral anaplastic pleomorphic xanthoastrocytoma with meningeal dissemination at first presentation. Childs Nerv. Syst. 20(2), 119-122 (2004).

13. Passone E, Pizzolitto S, D'agostini S et al. Non-anaplastic pleomorphic xanthoastrocytoma with neuroradiological evidences of leptomeningeal dissemination. Childs Nerv. Syst. 22(6), 614-618 (2006).

14. Mcnatt SA, Gonzalez-Gomez I, Nelson MD, Mccomb JG. Synchronous multicentric pleomorphic xanthoastrocytoma: case report. Neurosurgery 57(1), E191-E191 (2005).

15. Okazaki T, Kageji T, Matsuzaki K et al. Primary anaplastic pleomorphic xanthoastrocytoma with widespread neuroaxis dissemination at diagnosis - a pediatric case report and review of the literature. J. Neurooncol. 94(3), 431 (2009).

16. Smirniotopoulos JG. The new WHO classification of brain tumors. Neuroimaging Clin. N. Am. 9(4), 595-613 (1999).

17. Yoshino MT, Lucio R. Pleomorphic xanthoastrocytoma. Am. J. Neuroradiol. 13(5), 1330-1332 (1999).

18. Bucciero A, De Caro M, De Stefano V et al. Pleomorphic xanthoastrocytoma: clinical, imaging and pathological features of four cases. Clin. Neurol. Neurosurg. 99(1), 40-45 (1997).

19. Weldon-Linne CM, Victor TA, Groothuis DR, Vick NA. Pleomorphic xanthoastrocytoma. Ultrastructural and immunohistochemical study of a case with a rapidly fatal outcome following surgery. Cancer 52(11), 2055-2063 (1983).

20. Iwaki T, Fukui M, Kondo A, Matsushima T, Takeshita I. Epithelial properties of pleomorphic xanthoastrocytomas determined in ultrastructural and immunohistochemical studies. Acta Neuropathol. 74(2), 142-150 (1987).

21. Kyritsis AP, Zhang B, Zhang W et al. Mutations of the p16 gene in gliomas. Oncogene 12(1), 63-67 (1996).

22. Primavera J, Nikas DC, Zamani AA et al. Clear cell pleomorphic xanthoastrocytoma: case report. Acta Neuropathol. 102(4), 404-408 (2001)

23. Tonn JC, Paulus W, Warmuth-Metz M, Schachenmayr W, Sörensen N, Roosen K. Pleomorphic xanthoastrocytoma: report of six cases with special consideration of diagnostic and therapeutic pitfalls. Surgical Neurol. 47(2), 162-169 (1997).

24. Asano K, Miyamoto S, Kubo O, Kikkukawa T, Yagihashi A, Ohkuma H. A case of anaplastic pleomorphic xanthoastrocytoma presenting with tumor bleeding and cerebrospinal fluid dissemination. Brain Tumor Pathol. 23(1), 55-63 (2006). 
25. Tan TC, Ho LC, Yu CP, Cheung FC. Pleomorphic xanthoastrocytoma: report of two cases and review of the prognostic factors. J. Clin. Neurosci. 11(2), 203-207 (2004).

26. Perry A, Giannini C, Scheithauer BW et al. Composite pleomorphic xanthoastrocytoma and ganglioglioma: report of four cases and review of the literature. Am. Surgical Pathol. 21(7), 763-771 (1997).

27. Saikali S, Strat AL, Heckly A, Stock N, Scarabin J-M, Hamlat A. Multicentric pleomorphic xanthoastrocytoma in a patient with neurofibromatosis type 1: case report and review of the literature. J. Neurosurg. 102(2), 376-381 (2005).

28. Prayson RA, Morris Iii HH. Anaplastic pleomorphic xanthoastrocytoma. Archives Pathol. Lab. Med. 122(12), 1082 (1998).

29. Tekkök IH, Sav A. Anaplastic pleomorphic xanthoastrocytomas. Pediatr. Neurosurg. 40(4), 171-181 (2004).

30. Vajtai I, Varga Z. Prognostic markers of pleomorphic xanthoastrocytoma. Histopathology 33(4), 391-391 (1998).

31. Macaulay RJ, Jay V, Hoffman HJ, Becker LE. Increased mitotic activity as a negative prognostic indicator in pleomorphic xanthoastrocytoma: case report. J. Neurosurg. 79(5), 761-768 (1993).

32. Bayindir Ç, Balak N, Karasu A, Kasaroğlu D. Anaplastic pleomorphic xanthoastrocytoma. Childs Nerv. Syst. 13(1), 50-56 (1997).

33. Van Roost D, Kristof R, Zentner J, Wolf HK, Schramm J. Clinical, radiological, and therapeutic features of pleomorphic xanthoastrocytoma: report of three patients and review of the literature. J. Neurol. Neurosurg. Psychiatry 60(6), 690-692 (1996).

34. Dias-Santagata D, Lam Q, Vernovsky K et al. BRAF V600E mutations are common in pleomorphic xanthoastrocytoma: diagnostic and therapeutic implications. PLoS ONE 6(3), e17948 (2011).

-• Manuscript defining BRAF mutation as a common molecular feature of pleomorphic xanthoastrocytoma.

35. Tatevossian RG, Lawson AR, Forshew T, Hindley GF, Ellison DW, Sheer D. MAPK pathway activation and the origins of pediatric low-grade astrocytomas. J. Cell. Physiol. 222(3), 509-514 (2010).

36. Jacob K, Quang-Khuong DA, Jones DT et al. Genetic aberrations leading to MAPK pathway activation mediate oncogene-induced senescence in sporadic pilocytic astrocytomas. Clin. Cancer Res. 17(14), 4650-4660 (2011).

37. Maurer G, Tarkowski B, Baccarini M. Raf kinases in cancer - roles and therapeutic opportunities. Oncogene 30(32), 3477 (2011).

38. Ida CM, Rodriguez FJ, Burger PC et al. Pleomorphic xanthoastrocytoma: natural history and long-term follow-up. Brain Pathol. 25(5), 575-586 (2015).

39. Schindler G, Capper D, Meyer J et al. Analysis of BRAF V600E mutation in 1,320 nervous system tumors reveals high mutation frequencies in pleomorphic xanthoastrocytoma, ganglioglioma and extra-cerebellar pilocytic astrocytoma. Acta Neuropathol. 121(3), 397-405 (2011).

40. Chamberlain MC. Salvage therapy with BRAF inhibitors for recurrent pleomorphic xanthoastrocytoma: a retrospective case series. J. Neurooncol. 114(2), 237-240 (2013).

41. Horbinski C. To BRAF or not to BRAF: is that even a question anymore? J. Neuropathol. Exp. Neurol. $72(1), 2-7$ (2013).

42. Brown NF, Carter T, Kitchen N, Mulholland P. Dabrafenib and trametinib in BRAFV600E mutated glioma. CNS Oncol. 6(04), 291-296 (2017).

43. Nasuha NA, Daud AH, Ghazali MM et al. Molecular genetic analysis of anaplastic pleomorphic xanthoastrocytoma. Asian J. Surg. 26(2), $120-125$ (2003).

44. Giannini C, Hebrink D, Scheithauer BW, Dei Tos AP, James CD. Analysis of p53 mutation and expression in pleomorphic xanthoastrocytoma. Neurogenetics 3(3), 159-162 (2001).

45. Tada K, Shiraishi S, Kamiryo T et al. Analysis of loss of heterozygosity for chromosome 10 in patients with malignant astrocytic tumors: correlation with patient age and survival. J. Neurosurg. 95(4), 651-659 (2001).

46. Nduom EK, Wei J, Yaghi NK et al. PD-L1 expression and prognostic impact in glioblastoma. Neuro Oncol. 18(2), 195-205 (2016).

47. Johanns TM, Miller CA, Dorward IG et al. Immunogenomics of hypermutated glioblastoma: a patient with germline POLE deficiency treated with checkpoint blockade immunotherapy. Cancer Discov. 6(11), 1230-1236 (2016).

48. Indraccolo $\mathrm{S}$, Lombardi G, Fassan $\mathrm{M}$ et al. Genetic, epigenetic, and immunologic profiling of MMR-deficient relapsed glioblastoma. Clin. Cancer Res. 25(6), 1828-1837 (2019).

49. Zhao J, Chen AX, Gartrell RD et al. Immune and genomic correlates of response to anti-PD-1 immunotherapy in glioblastoma. Nat. Med. 25(3), 462-469 (2019).

50. Byun J, Hong SH, Kim Y-H, Kim JH, Kim CJ. Peritumoral edema affects the prognosis in adult pleomorphic xanthoastrocytoma: retrospective analysis of 25 patients. World Neurosurg. 114, e457-e467 (2018).

51. Lim S, Kim JH, Kim SA, Park ES, Ra YS, Kim CJ. Prognostic factors and therapeutic outcomes in 22 patients with pleomorphic xanthoastrocytoma. J. Korean Neurosurg. Soc. 53(5), 281 (2013).

52. Rutkowski MJ, Oh T, Niflioglu GG, Safaee M, Tihan T, Parsa AT. Pleomorphic xanthoastrocytoma with anaplastic features: retrospective case series. World Neurosurg. 95, 368-374 (2016).

53. Oh T, Kaur G, Madden M, Bloch O, Parsa AT. Pleomorphic xanthoastrocytomas: institutional experience of 18 patients. J. Clin. Neurosci. 21(10), 1767-1772 (2014). 
54. Perkins SM, Mitra N, Fei W, Shinohara ET. Patterns of care and outcomes of patients with pleomorphic xanthoastrocytoma: a SEER analysis. J. Neurooncol. 110(1), 99-104 (2012).

- A contemporary epidemiologic study of outcomes in patients with pleomorphic xanthoastrocytoma.

55. Pahapill PA, Ramsay DA, Del Maestro RF. Pleomorphic xanthoastrocytoma: case report and analysis of the literature concerning the efficacy of resection and the significance of necrosis. Neurosurgery 38(4), 822-829 (1996).

56. Mallick S, Benson R, Melgandi W, Giridhar P, Rath GK. Grade II pleomorphic xanthoastrocytoma: a meta-analysis of data from previously reported 167 cases. J. Clin. Neurosci. 54, 57-62 (2018).

57. Koga T, Morita A, Maruyama K et al. Long-term control of disseminated pleomorphic xanthoastrocytoma with anaplastic features by means of stereotactic irradiation. Neuro Oncol. 11(4), 446-451 (2009).

58. Brown NF, Carter T, Mulholland P. Dabrafenib in BRAFV600-mutated anaplastic pleomorphic xanthoastrocytoma. CNS Oncol. 6(1), 5-9 (2017).

59. Hong CS, Wang JL, Dornbos Iii D, Joehlin-Price A, Elder JB. BRAF-mutated pleomorphic xanthoastrocytoma of the spinal cord with eventual anaplastic transformation. World Neurosurg. 98, e871.e9-871.e15 (2017).

60. Lee EQ, Ruland S, Leboeuf NR, Wen PY, Santagata S. Successful treatment of a progressive BRAF V600E-mutated anaplastic pleomorphic xanthoastrocytoma with vemurafenib monotherapy. J. Clin. Oncol. 34(10), e87-e89 (2014).

61. Migliorini D, Aguiar D, Vargas M-I, Lobrinus A, Dietrich P-Y. BRAF/MEK double blockade in refractory anaplastic pleomorphic xanthoastrocytoma. Neurology 88(13), 1291-1293 (2017).

62. Hussain F, Horbinski CM, Chmura SJ, Yamini B, Lukas RV. Response to BRAF/MEK inhibition after progression with BRAF inhibition in a patient with anaplastic pleomorphic xanthoastrocytoma. Neurologist 23(5), 163-166 (2018).

63. Kaley T, Touat M, Subbiah V et al. BRAF inhibition in BRAF(V600)-mutant gliomas: results from the VE-BASKET study. J. Clin. Oncol.doi:10.1200/JCO.2018.78.9990 (2018) (Epub ahead of print).

-• A basket trial including pleomorphic xanthoastrocytomas evaluating the use of a BRAF inhibitor as monotherapy.

64. Thomas A, Tucker S, Nelson C, Nickerson J, Durham S, Homans A. Rare-30. Anaplastic pleomorphic xanthoastrocytoma with leptomeningeal dissemination responsive to BRAF inhibition and bevacizumab. Neuro Oncol. 19(Suppl. 6), vi216 (2017).

65. Lukas RV, Merrell RT. BRAF inhibition with concomitant tumor treating fields for a multiply progressive pleomorphic xanthoastrocytoma. CNS Oncol. 7(02), CNS10 (2018).

66. Horbinski C, Ligon KL, Brastianos $\mathrm{P}$ et al. The medical necessity of advanced molecular testing in the diagnosis and treatment of bain tumor patients. Neuro Oncol. doi:10.1093/neuonc/noz119 (2019) (Epub ahead of print).

\section{- Highlights the value of molecular testing in central nervous system tumors.}

